\title{
Hubungan antara citra tubuh dengan kecenderungan body dysmorphic disorder (BDD) pada remaja akhir laki-laki di Denpasar
}

\author{
Anak Agung Istri Galuh Ganeçwari dan Ni Made Ari Wilani \\ Program Studi Sarjana Psikologi, Fakultas Kedokteran, Universitas Udayana \\ ariwilani@unud.ac.id
}

\begin{abstract}
Abstrak
Masa remaja juga merupakan suatu tahap dalam perkembangan individu mengalami perubahan-perubahan yang sangat pesat diantaranya perubahan fisik. Hal ini yang mendasari remaja cenderung lebih banyak memperhatikan penampilan fisik. Pada masa sekarang bentuk tubuh remaja akhir laki-laki adalah bentuk tubuh atletis dan proporsional dengan bentuk tubuh kurus dengan otot. Tak jarang hal tersebut menimbulkan ketidakpuasan pada tubuh remaja akhir laki-laki, ketidakpuasan ini jika terjadi secara terus menerus maka dapat menyebabkan munculnya kecenderungan Body Dysmorphic Disorder. Individu dengan Body Dysmorphic Disorder (BDD) biasanya melebih-lebihkan daya tarik dari kecantikan wajah dan merendahkan penampilan sendiri. Salah satu faktor yang menyebabkan adalah citra tubuh, citra tubuh merupakan pemikiran seseorang tentang bagaimana penilaian dari orang lain terhadap bentuk tubuhnya. Adanya distorsi dan citra tubuh yang negatif yang menyebabkan munculnya ketidakpuasan tubuh pada remaja akhir laki-laki. Berdasarkan pemaparan tersebut tujuan penelitian ini untuk mengetahui hubungan antara citra tubuh dengan kecenderungan Body Dysmorphic Disorder (BDD) pada remaja akhir laki-laki di Denpasar. Penelitian ini menggunakan metode kuantitatif dengan subjek sejumlah 208 remaja akhir laki-laki dengan rentang usia 17-22 tahun yang merupakan mahasiswa di Denpasar yang dipilih dengan menggunakan teknik probability sampling yaitu cluster area. Instrumen penelitian terdapat dua, yaitu skala citra tubuh $(\mathrm{r}=0,912)$ dan skala kecenderungan Body Dysmorphic Disorder (BDD) $(0,909)$. Metode analisis menggunakan korelasi product moment dengan hasil signifikansi sebesar $0,007(\mathrm{p}<0,05)$, sehingga kesimpulan penelitian ini yaitu terdapat hubungan antara citra tubuh dengan kecenderungan Body Dysmorphic Disorder (BDD) pada remaja akhir laki-laki di Denpasar.
\end{abstract}

Kata kunci: Kecenderungan Body Dysmorphic Disorder (BDD), citra tubuh, remaja akhir laki-laki.

\begin{abstract}
Adolescence is also a stage in the development of individuals experiencing rapid changes such as physical changes. This underlying adolescents tend to pay more attention to physical appearance. In the present body shape of late adolescent male is an athletic and proportionate body shape with a thin body with muscles. Not infrequently it causes dissatisfaction in the body of late adolescent male, this dissatisfaction if it occurs continuously it can cause the emergence of the tendency Body Dysmorphic Disorder. Individuals with Body Dysmorphic Disorder (BDD) usually overestimate the attractiveness of facial beauty and degrade their own appearance. One of the contributing factors is body image, body image is one's thinking about how others judge their body shape. The existence of distortion and negative body image that causes the emergence of dissatisfaction of the body in late adolescent male. Based on the exposure, the purpose of this study was to determine the relationship between body image with Body Dysmorphic Disorder (BDD) tendency in late adolescent male in Denpasar. This research uses quantitative method with subject of 208 final adolescent male with age range 17-22 year which is student in Denpasar chosen by using probability sampling technique that is cluster area. There were two research instruments, is body image scale $(r=0,912)$ and Body Dysmorphic Disorder (BDD) tendency scale $(0,909)$. The method of analysis using product moment correlation with significance result of 0,007 ( $p<0,05)$, so that conclusion of this research that there is correlation between body image with Body Dysmorphic Disorder (BDD) tendency in adolescent final adolescent in Denpasar.
\end{abstract}

Keywords: Tendencies of Body Dysmorphic Disorder (BDD), body image, late adolescent male. 


\section{LATAR BELAKANG}

Remaja merupakan periode transisi perkembangan antara masa kanak-kanak dengan masa dewasa, yang melibatkan perubahan-perubahan biologis, kognitif, sosio-emosional (Santrock, 2007). Masa remaja adalah suatu tahap dalam perkembangan kehidupan indvidu yang sangat penting dan berdampak luas bagi perkembangan berikutnya di masa dewasa, jika pada tugas perkembangan remaja tidak optimal maka menjadi penghambat bagi perkembangan individu selanjutnya. Masa remaja juga merupakan suatu tahap dalam perkembangan individu mengalami perubahan-perubahan yang sangat pesat diantaranya perubahan fisik (Sarwono, 2012). Pada tahap perkembangannya, remaja mulai memiliki kesadaran untuk membentuk identitas dirinya dan ketertarikan terhadap lawan jenis. Hal ini yang mendasari remaja cenderung lebih banyak memperhatikan penampilan fisik (Santrock, 2011).

Masa sekarang banyak remaja laki-laki termotivasi untuk mencapai penampilan fisik yang diinginkan. Pada remaja akhir laki-laki umumnya ingin memiliki konsep tubuh yang ideal yaitu tubuh berisi, berdada bidang, serta biseps yang menonjol (McCabe, 2004). Pada masa ini juga remaja akhir laki-laki memiliki tahap perkembangan kognitif yaitu pada tahap operasional formal yang umumnya remaja akhir lakilaki akan menetapkan tujuan yang diinginkan. Hal tersebut tak terkecuali untuk menetapkan tujuan mencapai bentuk tubuh yang ideal walaupun hal tersebut harus mengeluarkan biaya dan waktu yang tidak sedikit (Piaget dalam Papalia, 2008).

Adapun penelitian terkait waktu yang dihabiskan remaja lakilaki yaitu terdapat $17 \%$ laki-laki menghabiskan waktu tiga tahun dan $11 \%$ lainnya menghabiskan waktu lima tahun untuk membentuk tubuh. Angka-angka ini sangat mirip dengan survei yang diperoleh dari perempuan (Pope dalam Cash \& Pruzinsky, 2002). Pendapat lain dari Corson dan Andersen (dalam Cash \& Pruzinzky, 2002) mengungkapkan bahwa faktanya laki-laki lebih khawatir mengenai berat tubuh daripada perempuan, karena aspirasi laki-laki jauh lebih kompleks dibandingkan dengan norma perempuan yang diterima mengenai kelangsingan. Pope (dalam Cash \& Pruzinsky, 2002) mengatakan bahwa laki-laki lebih memiliki ide untuk membentuk tubuhnya dan memiliki otot-otot ketika mengubah tubuh yang diinginkan. Penelitian lain dari Jones dan Crawford (2005) bahwa remaja akhir laki-laki ingin memiliki tubuh maskulinitas yaitu sebesar 59\% remaja akhir laki-laki menginginkan tubuh yang berisi karena merasa tubuhnya kurus padahal hanya $25 \%$ yang benar-benar kurus.

Adapun tren bentuk tubuh pada remaja akhir laki-laki yang berkembang pada masa sekarang khususnya di Indonesia. Seorang remaja akhir laki-laki dikatakan menarik dan dianggap ideal jika memiliki bentuk tubuh atletis proporsional, dengan bentuk tubuh kurus namun dengan bentuk tubuh otot yang tidak berlebihan yang ditandai dengan indeks massa tubuh yang ideal bagi remaja akhir laki-laki, maka dari itu remaja akhir laki-laki akan melakukan berbagai cara untuk mendapatkan bentuk tubuh yang ideal (Maharani, 2016).

Tak jarang hal ini mengakibatkan timbulnya ketidakpuasan tubuh pada remaja. Ketidakpuasan pada tubuh umumnya terjadi pada remaja perempuan, namun faktanya remaja lakilaki juga memunculkan ketidakpuasan pada tubuh. Ketidakpuasan pada tubuh dapat terjadi ketika remaja akhir laki-laki memiliki pemikiran dan perasaan negatif mengenai tubuh. Lingkungan juga memiliki pengaruh yang besar terhadap cara remaja akhir laki-laki melihat dan merasakan tentang tubuh. Keluarga, teman-teman, kenalan, guru, dan media memberikan dampak tentang cara remaja melihat dan merasakan mengenai diri sendiri dan penampilan.

Masyarakat dalam segala usia juga dihujani dengan gambaran melalui media seperti televisi, majalah, internet dan iklan. Gambaran tersebut sering tidak realistis, seperti mempromosikan kecantikan dan penampilan yang ideal bagi remaja akhir laki-laki dalam kehidupan sosial. Masyarakat sangat memberikan pengaruh yang menegaskan bahwa dalam suatu budaya, tubuh yang kurus atau berotot adalah bentuk ideal untuk laki-laki dan jika bentuk tubuh tersebut tercapai maka akan tercipta kebahagian, kesuksesan, dan cinta. Ketika remaja akhir laki-laki tidak termasuk dalam kriteria bentuk tubuh tersebut, perasaan tidak puas pada tubuhnya mulai muncul dan berdampak pada kesejahteraan fisiologis dan psikologis remaja tersebut (Healey, 2014). Ketika ketidakpuasan pada tubuh remaja akhir laki-laki terjadi secara terus menerus maka dapat mengakibatkan sebuah gangguan psikologis, salah satunya adalah Body Dysmorphic Disorder (BDD). Individu dengan Body Dysmorphic Disorder (BDD) biasanya melebih-lebihkan daya tarik dari kecantikan wajah dan merendahkan penampilan sendiri. Sebuah penelitian mengatakan bahwa pasien dengan Body Dysmorphic Disorder (BDD) memiliki ide dengan kecantikan yang ideal (Phillips dalam Cash \& Pruzinsky, 2002).

Menurut Phillips (2009), Body Dysmorphic Disorder (BDD) pada umumnya mulai terlihat sejak seseorang memasuki masa remaja akhir pada laki-laki, bahkan dapat terjadi sejak kecil tetapi belum terdeteksi. Pada masa remaja itulah, remaja mulai semakin memperhatikan perubahan yang terjadi pada dirinya seperti ukuran dan bentuk tubuh. Beberapa individu yang menderita gangguan ini dapat menghabiskan waktu berjamjam secara berulang memandangi diri sendiri di cermin untuk mengecek kekurangan-kekurangannya. Individu dengan BDD memiliki ide bahwa beberapa aspek dari penampilan fisiknya tidak menarik, rusak, atau tidak benar dalam beberapa keadaan (Phillips dalam Cash \& Pruzinsky, 2002).

Ide tersebut biasa melibatkan aspek dari wajah atau kepala, yang lebih sering adalah kulit, rambut atau bahkan hidung. Beberapa bagian dari tubuh dari laki-laki dapat menjadi perhatian yang difokuskan, seperti pembentukan otot, ukuran penis dan kebotakan (Phillips dalam Cash \& Pruzinsky, 2002). Menurut Phillips (2009) pada karakteristik kecenderungan Body Dysmorphic Disorder (BDD) serupa dengan gejala Body Dysmorphic Disorder (BDD), namun pada tingkatan yang ringan. Individu dengan tingkat Body Dysmorpic Disorder yang ringan masih tetap dapat berfungsi secara sosial dalam hidupnya meskipun menyadari kekurangan yang dimiliki.

Salah satu faktor yang mengakibatkan munculnya ketidakpuasan pada tubuh sehingga mengarah pada kecenderungan Body Dysmorphic Disorder (BDD) adalah citra tubuh (Phillips, 2009). Menurut Honigman dan Castle 
(dalam Rini, 2004) citra tubuh merupakan penilaian individu terhadap tubuhnya, selain penilaian terhadap tubuhnya juga berkaitan dengan pemikiran individu tentang bagaimana penilaian dari orang lain terhadap bentuk tubuhnya.

Citra tubuh memang merupakan faktor dari timbulnya gejala Body Dysmorphic Disorder (BDD) (Phillips dalam Cash, 2012). Beberapa penelitian telah meneliti citra tubuh pada Body Dysmorphic Disorder (BDD). Sebuah studi yang membandingkan orang-orang dengan BDD dengan norma yang diterbitkan dalam Kuesioner Body-Self Relations Multidimensional menemukan bahwa individu yang memiliki Body Dysmorphic Disorder (BDD) secara signifikan kurang puas dengan penampilan dan individu dengan Body Dysmorphic Disorder (BDD) secara signifikan lebih banyak diinvestasikan dalam penampilan dibandingkan dengan norma individu itu sendiri (Phillips dalam Cash, 2012).

Adanya distorsi pada citra tubuh yang menyebabkan munculnya ketidakpuasan pada tubuh yaitu distorsi pada estismasi ukuran tubuh. Individu memiliki persepsi bahwa ukuran tubuhnya lebih besar atau lebih kecil dari keadaan sebenarnya, seperti contoh bahwa remaja akhir laki-laki ingin memiliki bentuk tubuh yang berisi padahal bentuk tubuhnya tidak benar-benar kurus. Hal lain juga adanya respon negatif yaitu memiliki perasaan dan pikiran negatif terhadap tubuh remaja akhir laki-laki yang memunculkan ketidakpuasan pada tubuh (Odgen, 2010). Hal tersebut mengarah pada citra tubuh negatif pada remaja akhir laki-laki yang menyebabkan remaja akhir laki-laki tidak menyukai bentuk tubuhnya, padahal hal ini berlawanan dengan tugas perkembangan remaja, yaitu remaja harus dapat menerima bentuk tubuhnya dan dapat memanfaatkan keadaan tubuhnya (Sarwono, 2012).

Adapun dua tipe citra tubuh menurut Healey (2014) yaitu individu dengan citra tubuh yang positif memiliki tingkat yang lebih tinggi dari kesehatan fisik dan psikologis, dan juga perkembangan individual yang baik. Citra tubuh yang positif memberikan pengaruh pada: yang pertama, tingkat self-esteem yang menentukan bagaimana perasaan remaja tentang diri sendiri. Semakin tinggi self-esteem individu maka semakin mudah individu bergaul dengan dirinya dan menyebabkan kebahagiaan dan kesejahteraan. Kedua adalah self-acceptance, semakin positif citra tubuh individu, maka semakin besar kemungkinan individu merasa nyaman dan bahagia dengan penampilan tersebut. Ketiga adalah pandangan dan perilaku yang sehat, citra tubuh yang positif mengarahkan pada gaya hidup yang seimbang dengan sikap yang lebih sehat dan praktik sehat. Remaja dengan citra tubuh yang negatif menjadi terpaku pada usaha untuk mengubah bentuk tubuh yang sebenarnya. Hal ini dapat mengakibatkan individu terlibat dengan praktik makan dan olahraga yang tidak sehat dengan harapan bahwa perubahan bentuk tersebut mengurangi perasaan negatif. Praktik ini juga biasanya tidak berhasil sesuai yang diinginkan (secara fisik dan emosional) dan menghasilkan perasaan negatif dan rasa bersalah yang lebih intens.
Denpasar merupakan salah satu kota yang memiliki perkembangan yang tak kalah pesat dengan ibukota Indonesia yaitu Jakarta dalam hal memperhatikan tubuh pada laki-laki. Di Denpasar, remaja akhir laki-laki kini makin memiliki perhatian pada tubuh, dapat dilihat dari semakin banyaknya pusat kebugaran yang berada di kawasan Denpasar dan juga makin banyaknya salon khusus laki-laki. Dalam sebuah survei yang telah dilakukan peneliti, terdapat 138 pusat kebugaran yang tersebar luas di Denpasar, sekitar 40\% remaja akhir lakilaki menjadi anggota dari salah satu pusat kebugaran tersebut. Tidak hanya pusat kebugaran, salon khusus untuk laki-laki juga semakin beredar di kawasan Denpasar yaitu sekitar 124 salon. Hal ini semakin meningkatkan peluang bagi remaja akhir laki-laki untuk mencapai penampilan fisik yang diinginkan (Ganecwari, 2018).

Studi pendahuluan telah dilakukan pada Maret 2017 terhadap dua subjek remaja akhir laki-laki di Denpasar berumur 20 dan 21 tahun menggambarkan perhatian terhadap tubuh yang mengarah pada citra tubuh yang negatif. Dua subjek memiliki ketidakpuasan pada tubuhnya, subjek pertama berumur 21 tahun memilih untuk mengubah tubuhnya dikarenakan memiliki ketidakpuasan terhadap tubuhnya yang besar atau gemuk, karena membuat dirinya tidak dapat mencari ukuran celana yang tepat. Subjek pertama menciptakan citra tubuh yang ideal untuk laki-laki, dan saat ini subjek pertama juga ingin memiliki citra tubuh yang berotot. Subjek pertama melakukan diet dengan makan sehari sekali tanpa makan nasi dan hanya memakan tempe, tahu dan sayur tauge yang subjek lakukan selama sebulan dan turun sebanyak $10 \mathrm{~kg}$. Subjek pertama saat ini masih memperhatikan tubuhnya dengan berolahraga sebanyak lima kali dalam seminggu selama dua jam, dan menjaga pola dietnya. Jika dirasa subjek makan dalam jumlah yang banyak dalam satu hari, subjek akan mengganti keesokan harinya untuk tidak makan. Subjek pertama memiliki perhatian besar pada rambutnya hal ini dikarenakan subjek pertama memiliki rambut yang panjang. Hal yang dilakukan pada subjek pertama adalah dengan melakukan perawatan pada rambutnya sehari-hari di rumah atau jika ada waktu subjek melakukan perawatan di salon. Subjek pertama saat ini tetap melakukan diet karena subjek masih merasa bentuk tubuhnya kurang ideal, walaupun temantemannya menyuruh untuk tidak diet. Perhatian pada tubuh subjek dilihat dari perilaku mengecek tubuhnya setiap melihat cermin di rumahnya atau di rumah teman subjek. Subjek saat ini memiliki keinginan mengembangkan tubuhnya agar lebih berotot dengan tujuan untuk meningkatkan penampilannya. Perilaku yang ditunjukan pada subjek pertama mengarah pada citra tubuh negatif, dikarenakan subjek mengembangkan citra tubuh yang ideal yaitu ingin memiliki bentuk tubuh yang berotot.

Subjek kedua berumur 20 tahun memiliki rasa tidak puas pada tubuhnya karena memiliki bentuk tubuh yang besar atau gemuk sehingga memutuskan untuk menurunkan berat badan sebanyak $30 \mathrm{~kg}$ dalam waktu tiga bulan dengan melakukan diet mayo, diet mayo merupakan program diet dengan tidak mengkonsumsi makanan ataupun minuman yang mengandung garam. Subjek juga melakukan diet OCD (Obsessive Corbuzier's Diet), diet OCD merupakan penetapan jendela 
makan dengan mengatur waktu untuk makan dan puasa, jendela makan dimulai pukul 11 atau pukul 12 dengan waktu bebas makan selama 8 jam. Setelah berat badan turun, subjek kedua tetap merasa tidak puas dengan bentuk tubuhnya dan akhirnya membentuk badannya dengan pergi ke pusat kebugaran. Subjek mengatakan bahwa dirinya melakukan latihan otot untuk menunjang penampilannya. Subjek kedua juga menciptakan citra tubuh yang ideal terhadap dirinya, subjek berpikir bahwa menjadi berotot adalah hal yang baik bagi dirinya. Subjek kedua juga memiliki waktu yang lama untuk memperbaiki penampilannya. Subjek kedua membentuk tubuh dengan melakukan diet yaitu hanya minum air selama $350 \mathrm{ml}$ selama sehari, selain itu subjek kedua didukung dengan suplemen agar mendapatkan hasil yang maksimal dikarenakan subjek kedua pernah mengikuti lomba binaraga. Perilaku tersebut menunjukkan bahwa subjek memiliki citra tubuh yang negatif (Ganeçwari, 2018).

Berdasarkan hasil studi pendahuluan tersebut menunjukan bagaimana gambaran remaja akhir laki-laki di Denpasar yang memiliki citra tubuh cenderung negatif, yang Nampak dari berbagai usaha yang dilakukan untuk mendapatkan penampilan ideal. Hal itu dapat pula kecenderungan Body Dysmorphic Disorder (BDD). Penelitian tentang kecenderungan Body Dysmorphic Disorder (BDD) lebih banyak dilakukan pada remaja perempuan, sehingga berdasarkan pemaparan tersebut, penelitian ini perlu dilakukan untuk mengetahui bagaimana hubungan antara citra tubuh dengan kecenderungan Body Dysmorphic Disorder (BDD) pada remaja akhir laki-laki di Denpasar.

\section{METODE PENELITIAN}

\section{Variabel dan Definisi Operasional}

Variabel bebas dalam penelitian ini adalah citra tubuh, serta variabel tergantung dalam penelitian ini adalah kecenderungan Body Dysmorphic Disorder (BDD). Definisi operasional dari masing-masing variabel dalam penelitian diantaranya sebagai berikut:

\section{Citra Tubuh}

Citra tubuh adalah gambaran mental dari seseorang mengenai bentuk tubuhnya. Bagaimana persepsi, pikiran dan perasaan terhadap tubuh individu dapat dilihat baik secara negatif ataupun positif. Dalam penelitian ini citra tubuh diukur melalui dimensi citra tubuh yang dikemukakan oleh Cash dan Pruzinsky (2002), dimensi tersebut diukur menggunakan skala Likert. Makin tinggi skor yang diperoleh, maka makin positif citra tubuh remaja akhir laki-laki. sebaliknya makin rendah skor maka makin negatif citra tubuh yang dimiliki oleh remaja akhir laki-laki.

Kecenderungan Body Dysmorphic Disorder (BDD)

Body Dysmorphic Disorder (BDD) merupakan gangguan yang mengakibatkan individu memiliki ide mengenai bayangan cacat pada tubuh individu yang dirasakan secara nyata dan di lebih-lebihkan namun tetap tertangani dan dapat mencapai hasil yang baik, meski menyadari kecacatan yang dimiliki. Dalam penelitian ini kecenderungan Body Dysmorphic Disorder (BDD) diukur melalui ciri-ciri Body Dysmorphic Disorder (BDD) yang dikemukakan oleh Phillips (2009), ciriciri tersebut diukur menggunakan skala Likert. Makin tinggi skor yang diperoleh maka makin tinggi remaja akhir laki-laki memiliki kecenderungan Body Dysmorphic Disorder (BDD). Sebaliknya, makin rendah skor maka makin rendah remaja akhir laki-laki memiliki kecenderungan Body Dysmorphic Disorder (BDD).

\section{Responden}

Populasi yang digunakan dalam penelitian ini adalah remaja akhir laki-laki yang berada di Denpasar. Sampel dalam penelitian ini memiliki karakteristik yaitu berjenis kelamin laki-laki, berusia 17-22 tahun, dan merupakan mahasiswa.

Teknik sampling yang digunakan adalah probability sampling yaitu cluster area. Cluster sampling atau sampling area digunakan jika sumber data atau populasi sangat luas misalnya penduduk suatu provinsi, kabupaten, atau karyawan perusahaan yang tersebar di seluruh provinsi. Untuk menentukan mana yang dijadikan sampelnya, maka wilayah populasi terlebih dahulu ditetapkan secara acak (Sugiyono, 2016). Menurut Roscoe (dalam Sugiyono, 2016) mengatakan bahwa ukuran sampel yang layak dalam penelitian adalah antara 30-500. Jumlah sampel pada penelitian ini berjumlah 208 subjek.

\section{Tempat dan Waktu Penelitian}

Peneliti melakukan pengambilan data pada hari Kamis, 8 Februari 2018, peneliti terlebih dahulu mencari daerah di bagian Denpasar Timur yang berada di Kampus Sudirman Universitas Udayana. Hari Jumat, 9 Februari 2018 kemudian dilakukan di Denpasar Selatan, tepatnya kawasan Renon dengan mencari rumah makan ataupun kedai yang berdekatan dengan kampus STIKOM (Sekolah Tinggi Ilmu Komputer) Bali. Hari Senin, 13 Februari 2018 dilanjutkan dengan mencari bagian Denpasar Utara tepatnya di Jalan Kamboja.

\section{Alat Ukur}

Alat ukur dalam penelitian ini menggunakan skala citra tubuh yang disusun berdasarkan teori Cash dan Pruzinsky (2002), yang terdiri dari 25 aitem pernyataan dan skala kecenderungan Body Dysmorphic Disorder (BDD) yang disusun berdasarkan teori Phillips (2009), yang terdiri dari 20 aitem pernyataan. Pernyataan dalam penelitian ini terdiri dari aitem-aitem favorable dan unfavorable, dan skala dalam penelitian ini menggunakan empat pilihan jawaban, diantaranya: sangat sesuai (SS), sesuai (S), tidak sesuai (TS), sangat tidak sesuai (STS).

Azwar (2015) menyatakan uji validitas dan reliabilitas digunakan guna mengetahui suatu skala dapat menghasilkan data akurat sesuai dengan tujuan ukur skala. Validitas isi dilakukan dengan menggunakan professional judgement untuk diminta pendapatnya tentang instrumen yang telah disusun, para ahli akan memberikan keputusan; instrumen dapat digunakan tanpa perbaikan. Ada perbaikan, dan mungkin dirombak total. Validitas konstruk dilakukan dengan cara mengkorelasikan skor butir dengan skor total. Bila koefisien korelasi lebih dari 0,30 atau 0,25 maka instrumen dikatakan valid dengan menggunakan metode Cronbach Alpha (Sugiyono, 2016). Penelitian ini juga melakukan uji reliabilitas alat ukur dengan menggunakan Cronbach Alpha, dikatakan 
reliabel jika koefisien reliabilitas minimal 0,60 (Sugiyono, 2016).

Hasil uji validitas citra tubuh mendapatkan koefisien korelasi yang valid dengan aitem total berkisar antara 0,280 sampai 0,694, dengan koefisien reliabel sebesar 0,912. Pada hasil uji validitas kecenderungan Body Dysmorphic Disorder (BDD) memperoleh koefisien korelasi aitem-total berkisar antara 0,268 sampai 0,795, dengan koefisien reliabel sebesar 0,909.

\section{Teknik Analisis Data}

Teknik analisis data pada penelitian ini menggunakan analisisi korelasi Product Moment Pearson dengan bantuan program SPSS 25.0 for MacOs. Sebelum dilakukan uji analisis data penelitian, dilakukan terlebih dahulu uji asumsi data, diantaranya uji normalitas dan uji linearitas. Uji normalitas menggunakan uji Kolmogorov-Smirnov dengan bantuan SPSS 25.0 for MacOs. Uji linearitas menggunakan Test of Linearity dengan bantuan SPSS 25.0 for MacOs.

\section{HASIL PENELITIAN}

\section{Karakteristik Subjek}

Subjek dalam penelitian ini adalah remaja yang sedang menempuh perguruan tinggi dan merupakan remaja akhir yang berusia 17-22 tahun dengan jumlah 208 orang. Mayoritas subjek pada penelitian ini merupakan remaja akhir laki-laki berusia 20 tahun dengan jumlah 55 subjek dengan presentase sebesar $26,44 \%$.

\section{Deskripsi Data Penelitian}

Kategorisasi data penelitan bertujuan untuk menempatkan subjek ke dalam kelompok-kelompok yang terpisah secara berjenjang menurut suatu kontinum berdasar atribut yang diukur. Kontinum jenjang ini meliputi sangat rendah, rendah, sedang, tinggi, dan sangat tinggi. Penentuan kategorisasi dengan skor skala dilakukan dengan menggunakan nilai mean dan standar deviasi teoretis (Azwar, 2015).

Berdasarkan hasil deskripsi statistik data penelitian pada tabel 1 (terlampir) dapat dijelaskan nilai-nilai tersebut memberikan makna yaitu variabel citra tubuh memiliki mean teoretis sebesar 62,5 dan mean empiris sebesar 63,51 dengan perbedaan sebesar -1,01, dengan nilai t sebesar 2,167 $\mathrm{p}=$ (0,031). Hal ini menunjukkan bahwa subjek penelitian memiliki taraf citra tubuh yang sedang karena nilai mean empiris dan mean teoretis tidak memiliki perbedaan yang terlalu jauh $(63,51>62,5)$. Berdasarkan penyebaran frekuensi, subjek dalam penelitian ini memiliki rentang skor antara 49 sampai dengan 84. Pada variabel kecenderungan Body Dysmorphic Disorder (BDD) memiliki mean teoretis sebesar 50 dan mean empiris sebesar 42,26 dengan perbedaan sebesar 7,74 , dengan nilai $\mathrm{t}$ sebesar $-19,493 \mathrm{p}=(0,000)$. Hal ini menunjukkan bahwa subjek penelitian memiliki taraf kecenderungan Body Dysmorphic Disorder (BDD) yang rendah karena nilai mean empiris lebih rendah dibandingkan nilai mean teoretis $(50>42,26)$. Berdasarkan penyebaran frekuensi, subjek dalam penelitian ini memiliki rentang skor antara 26 sampai dengan 57.

\section{Uji Asumsi Penelitian}

Uji normalitas dilakukan dengan menggunakan KolmogorovSmirnov, suatu sebaran dapat dikatakan normal jika hasil $\mathrm{p}>$ 0.05 dan sebaliknya dikatakan tidak normal jika hasil $\mathrm{p}<0.05$ (Sugiyono, 2016). Uji normalitas menggunakan bantuan software SPSS 25.0 for MacOS dalam melakukan pengolahan data. Hasil uji normalitas data penelitian dapat dilihat pada tabel 2 (terlampir). Berdasarkan hasil uji normalitas menunjukkan bahwa data berdistribusi normal dengan hasil signifikansi 0,200 ( $\mathrm{p}>0,05)$.

Uji linearitas dilakukan untuk mengetahui apakah terdapat hubungan yang linear antara kedua variabel penelitian, yaitu adanya hubungan antara skor variabel bebas dan tergantung yang menunjuk garis sejajar atau tidak. Uji linearitas dilakukan dengan menggunakan Test of Linearity pada program SPSS 25.0 for MacOS. Hubungan dua variabel dikatakan signifikan linear jika $\mathrm{p}<0.05$ dan sebaliknya dikatakan tidak linear jika $\mathrm{p}>0.05$. Hasil uji linearitas data penelitian dapat dilihat pada tabel 3 (terlampir). Berdasarkan hasil uji linearitas pada keluaran tabel 3, menunjukkan bahwa nilai Sig. Linearity sebesar 0,008. Karena nilai Sig.0,008< 0,05 maka terdapat hubungan linear secara signifikan antara variabel citra tubuh dengan kecenderungan Body Dysmorphic Disorder (BDD).

\section{Uji Hipotesis}

Uji hipotesis dilakukan untuk mengetahui jawaban sementara pada rumusan penelitian diterima atau ditolak. Uji hipotesis pada penelitian ini menggunakan analisis Korelasi Product Moment dengan bantuan program SPSS 25.0 for MacOS.

Analisis korelasi Product Moment adalah teknik yang digunakan untuk menguji hipotesis tentang hubungan antara satu variabel independen dengan satu variabel dependen (Sugiyono, 2016). Hasil uji korelasi Product Moment Pearson sederhana pada penelitian ini dapat dilihat pada tabel 4 (terlampir). Dari tabel tersebut diperoleh signifikansi sebesar 0,007 dengan korelasi pearson sebesar -0,186 pada signifikansi sebesar 1\%. Kedua variabel dikatakan memiliki hubungan apabila taraf signifikansi kurang dari 0,05 (Sig < $0,05)$, sehingga hipotesis alternatif $(\mathrm{Ha})$ pada penelitian ini diterima yang dapat dijelaskan bahwa terdapat hubungan antara citra tubuh dengan kecenderungan Body Dysmorphic Disorder (BDD) pada remaja akhir laki-laki. Korelasi pearson sebesar -0,186 menunjukan bahwa kedua variabel memiliki derajat hubungan yang sedang. Kecenderungan Body Dysmorphic Disorder (BDD) tidak sepenuhnya dipengaruhi oleh citra tubuh, terdapat faktor lain juga yang memengaruhi munculnya kecenderungan Body Dysmorphic Disorder (BDD). Hasil korelasi menunjukkan angka negatif memiliki arti bahwa hubungan kedua variabel adalah hubungan negatif. Hal ini berarti semakin tinggi variabel citra tubuh maka semakin rendah kecenderungan Body Dysmorphic Disorder (BDD). 


\section{PEMBAHASAN DAN KESIMPULAN}

Berdasarkan hasil penelitian yang dilakukan diperoleh hasil bahwa terdapat hubungan antara citra tubuh dengan kecenderungan Body Dysmorphic Disorder (BDD) pada remaja akhir laki-laki di Denpasar. Penelitian ini memperoleh hasil signifikansi sebesar $0,007(\mathrm{p}<0,05)$ yang artinya terdapat hubungan antara citra tubuh dengan kecenderungan Body Dysmorphic Disorder (BDD) pada remaja akhir laki-laki. Hal ini didukung oleh teori Phillips (2009) yang mengemukakan bahwa individu dengan Body Dysmorphic Disorder (BDD) memiliki masalah pada citra tubuh dengan bagaimana individu melihat penampilan fisik bukan melihat dengan bagaimana dirinya terlihat sebenarnya. Bayangan tersebut sulit dijelaskan karena beberapa orang dengan BDD berpikir bahwa individu terlihat sangat buruk, dan menolak dengan keras kata bayangan.

Individu khawatir jika membayangkan kekurangan fisiknya, karena mungkin dianggap tidak normal. Pendapat lain dari Thompson (2002), bahwa Body Dysmorphic Disorder (BDD) merupakan salah satu gangguan citra tubuh sebagai taksiran terlalu tinggi terhadap ukuran tubuh tertentu ketika dibandingkan dengan ukuran yang objektif. Citra tubuh merupakan gambaran mental individu mengenai bentuk tubuhnya, tentang bagaimana persepsi, pikiran dan perasaan remaja terhadap tubuh dapat dilihat secara negatif maupun positif. Ketika remaja akhir laki-laki memiliki citra tubuh yang negatif remaja umumnya mulai melakukan cara-cara yang tidak sehat untuk mendapatkan bentuk tubuh atau gambaran tubuh yang diinginkan, berbanding terbalik dengan remaja yang memiliki citra tubuh positif. Berbeda dengan remaja akhir laki-laki dengan citra tubuh yang positif cenderung menerapkan pola hidup sehat dan menghargai ataupun menerima keadaan tubuhnya (Haeley, 2014).

Citra tubuh yang negatif menciptakan ketidakpuasan pada tubuh. Individu tidak puas pada tubuhnya memiliki masalah pada komponen sikap dari citra tubuhnya, komponen sikap ini berisi kepuasan individu terhadap penampilan fisiknya, baik dari wajah dan keseluruhan tubuh individu. Individu yang memiliki ketidakpuasan pada tubuh juga terjadi ketika individu memiliki distorsi pada citra tubuhnya, distorsi ini menyebabkan individu memiliki kesalahan persepsi pada penampilan fisik secara realita, dikarenakan individu ingin memiliki penampilan fisik yang ideal sesuai yang diharapkan. Gangguan pada distorsi citra tubuh dikarenakan indvidu memiliki masalah pada komponen persepsi dari citra tubuh (Rudd \& Lennon, 2000)

Pada remaja akhir laki-laki masa sekarang juga telah memiliki bentuk ideal sesuai yang diharapkan. Hal tersebut didukung oleh penelitian yang dilakukan Kirkpatrick (dalam Grogan, 2008) menunjukkan bahwa ada prasangka budaya umum yang mendukung bentuk tubuh mesomorphic. Laki-laki dengan bentuk ini ditetapkan berbagai macam ciri kepribadian positif termasuk menjadi kuat, bahagia, membantu dan berani. Dapat dikatakan bahwa bentuk tubuh yang berotot merupakan cerminan maskulin yang ideal karena bentuk tubuh tersebut mewakili kekuasaan, kekuatan, dan agresi.
Berdasarkan hal tersebut dapat dikatakan bahwa citra tubuh sebagai faktor utama secara psikologis. Hal ini juga dikemukakan oleh Phillips (2009) bahwa faktor psikologis dalam terjadinya kecenderungan Body Dysmorphic Disorder (BDD) dalam sebuah penelitian menunjukkan bagi orangorang dengan BDD, ada perbedaan besar antara bagaimana individu tersebut berpikir dirinya benar-benar terlihat dan bagaimana individu melihat dirinya ideal serta bagaimana individu berpikir individu tersebut harus terlihat. Individu cenderung meremehkan daya tarik sendiri dan melebihlebihkan daya tarik orang lain, yang mungkin lebih meningkatkan perbedaan ini.

Pendapat tersebut didukung oleh penelitian yang dilakukan Pramarta dan Siswadi (2015) mengenai penelitian yang berjudul Studi Deskriptif Mengenai Citra Tubuh pada Remaja Pria di SMA Negeri 11 Kota Bandung. Hasil ditemukan bahwa remaja laki-laki di SMA Negeri 11 Bandung memiliki citra tubuh yang negatif lebih banyak dibandingkan yang positif. Hal tersebut dikarenakan kesalahan persepsi yang dimiliki remaja laki-laki mengenai bentuk tubuhnya karena remaja laki-laki menganggap bahwa tubuhnya tidak sesuai dengan kenyataan atau harapan sendiri, serta remaja laki-laki mencemaskan bagaimana tubuhnya terlihat, sama seperti kebanyakan remaja perempuan, namun remaja laki-laki cenderung bermasalah pada tinggi badan dan masalah otot.

Penelitian lain yang juga mendukung adalah penelitian yang dilakukan oleh Ashari dan Murti (2017) yang berjudul Perbedaan Body Image Remaja Akhir Laki-laki Ditinjau dari Keikutsertaan dalam Gym. Memiliki hasil bahwa terdapat perbedaan yang signifikan pada remaja akhir laki-laki yang mengikuti gym, hal ini dikarenakan remaja akhir laki-laki yang mengikuti gym memiliki tingkat citra tubuh yang tinggi dibandingkan dengan remaja akhir laki-laki yang tidak melakukan gym. Hal ini dikarenakan remaja akhir laki-laki yang mengikuti gym memiliki perhatian pada tubuh agar tubuhnya sesuai dengan yang diinginkan.

Adapun penelitian lain yang mendukung hubungan antara citra tubuh dengan kecenderungan Body Dysmorphic Disorder (BDD) yaitu penelitian yang dilakukan oleh Gracia (2015) yang berjudul Hubungan antara Body Image terhadap Kecenderungan Body Dysmorphic Disorder pada Mahasiswa PKK Psikologi Mercubuana Jakarta yang melakukan selfie di Media Sosial (Instagram atau Facebook) yang memperoleh signifikansi sebesar 0,005 yang memiliki arti bahwa terdapat hubungan antara citra tubuh dengan kecenderungan Body Dysmorphic Disorder (BDD).

Kedua variabel dalam penelitian ini memiliki derajat hubungan yang sedang, dikarenakan ada faktor lain yang memengaruhi kecenderungan Body Dysmorphic Disorder (BDD) yaitu menurut Phillips (dalam Cash, 2012) menyatakan bahwa sekitar $60 \%$ orang dengan Body Dysmorphic Disorder (BDD) sering mendapatkan ejekan atau ejekan yang parah mengenai penampilan selama masa kanak-kanak atau masa remaja. Tidak hanya ejekan, penganiayaan masa kanak-kanak, diabaikan secara emosional atau pelecehan emosional, 
kekerasan atau penelantaran serta kekerasan seksual turut serta memengaruhi Body Dysmorphic Disorder.

Pada penelitian ini citra tubuh pada subjek ini memiliki skor kategorisasi sedang yang memiliki arti bahwa subjek pada penelitian ini merasa memiliki kekurangan pada tubuhnya, namun masih merasa puas terhadap bentuk tubuhnya dengan melakukan berbagai cara untuk menutupi kekurangannya. Hal ini dikarenakan secara umum, remaja laki-laki menjadi lebih puas ketika melewati masa pubertas sehubungan dengan meningkatnya massa otot (Phillips dalam Santrock, 2011). Dengan demikian, dapat dikatakan remaja akhir laki-laki rentang usia 17-22 tahun telah melewati masa pubertas, mengingat masa pubertas pada laki-laki dimulai pada usia 10 dan berakhir pada usia 13 atau 17 tahun (Santrock, 2011). Ketika remaja akhir laki-laki sudah merasa puas dengan bentuk tubuhnya, remaja akhir laki-laki cenderung akan menerima keadaan dirinya.

Dalam sebuah penelitian yang dilakukan oleh Stuard dan Laraia (2005) mengatakan bahwa citra tubuh adalah sesuatu yang dinamis. Hal tersebut dikarenakan dapat berubah secara berkelanjutan seiring adanya pengalaman dan persepsi yang baru. Hal ini juga didukung oleh penelitian yang dilakukan oleh Waller dan Banner (2002) yang menyatakan bahwa citra tubuh dapat menjadi suatu konstruk yang dinamis dan bergantung pada faktor sosial dan psikologis individu.

Pada penelitian ini kategori skor dari kecenderungan Body Dysmorphic Disorder memiliki rentang nilai yang rendah, yang artinya tidak semua remaja akhir laki-laki mengarah pada kecenderungan Body Dysmorphic Disorder (BDD). Hal ini dikarenakan menurut Phillips (2009) dalam perbedaan gender pada penderita Body Dysmorphic Disorder pada lakilaki yang lebih fokus merasakan ketidakpuasan pada area alat kelamin dan pembetukan otot, berbeda jika dibandingkan dengan perempuan yang memiliki cakupan area yang luas pada tubuhnya. Pada dasarnya penderita Body Dysmorphic Disorder (BDD) memiliki proporsi yang menyerupai antara perempuan dan laki-laki. Pernyataan tersebut juga didukung dari penelitian yang dilakukan oleh (Phillips \& Menard, 2006) yang berjudul Gender Similarities and Differences in 200 Individuals with Body Dysmorphic Disorder. Hasilnya menunjukan bahwa terdapat lebih banyak kesamaan dari perbedaan antara laki-laki dan perempuan, namun banyak perbedaan gender ditemukan.

Laki-laki lebih cenderung terobsesi dengan alat kelamin, membentuk tubuh, dan rambut kusut atau botak; angkat beban secara berlebihan; dan memiliki gangguan penggunaan zat. Sebaliknya, perempuan lebih cenderung terobsesi dengan kulit, perut, berat badan, payudara atau dada, pantat, paha, kaki, pinggul, jari kaki, dan rambut tubuh atau wajah yang berlebihan, dan perempuan terlalu memperhatikan area tubuh lebih banyak. Perempuan juga melakukan perilaku yang lebih berulang dan aman, dan lebih cenderung menyamar dan menggunakan teknik penyamaran tertentu, memeriksa cermin, mengganti pakaian, dan memiliki gangguan makan. Dengan demikian, perempuan cenderung memiliki citra tubuh yang negatif, karena perempuan lebih banyak memiliki perasaan khawatir tentang kekurangan yang dirasakan di depan umum, lebih terganggu saat memikirkan seseorang memperhatikan kekurangan yang dirasakan, dan lebih sering menyamarkan tubuh dan mengubah posisi tubuh untuk menyembunyikan kekurangan yang dirasakan.

Penelitian lain yang dilakukan Phillips dan Menard (2006) mengungkapkan laki-laki lebih menerima kerusakan atau kekurangan yang dirasakan meskipun kerusakan dari Body Dysmorphic Disorder (BDD). Hal lain juga disebabkan bahwa citra tubuh remaja akhir laki-laki pada penelitian ini tidak pada kategori rendah, sehingga citra tubuh remaja akhir laki-laki pada penelitian ini tidak memiliki citra tubuh yang negatif yang dapat menyebabkan kecenderungan Body Dysmorphic Disorder (BDD). Melainkan pada kategori sedang, yaitu remaja akhir laki-laki pada penelitian ini merasa memiliki kekurangan namun tetap merasa puas dengan bentuk tubuhnya.

Maka simpulan dari pemaparan diatas bahwa terdapat hubungan antara citra tubuh dengan kecenderungan Body Dysmorphic Disorder pada remaja akhir laki-laki di Denpasar, dengan derajat hubungan kedua variabel pada taraf sedang.

\section{Keterbatasan Penelitian}

Keberhasilan dan akurasi temuan data dalam penelitian bergantung pada berbagai faktor dan aspek. Maka penelitian ini tentunya masih terdapat beberapa kelemahan dalam prosesnya. Pertama, aitem dalam angket atau kuesioner dalam penelitian ini kurang bervariasi dan kurang menyampaikan maksud serta tujuan dari penelitian ini. Kedua, pengambilan data dilakukan pada siang hari sehingga tidak efektif dalam pengerjaan kuesioner yang dilakukan oleh masing-masing subjek. Ketiga. ketika mengisi kuesioner, peneliti tidak langsung memeriksa kembali dengan teliti setiap aitem pada skala, sehingga beberapa kuesioner terpaksa digugurkan ketika akan melakukan uji analisis data dikarenakan ada beberapa kuesioner yang tidak memenuhi syarat. Keempat, keterbatasan lainnya terletak pada subjek penelitian, yang mana subjek pada penelitian ini tidak hanya tertuju pada subjek yang melakukan latihan pada otot.

\section{KESIMPULAN}

Berdasarkan hasil dan pembahasan yang telah dipaparkan pada penelitian ini, maka tersimpul beberapa hal yaitu, terdapat hubungan antara citra tubuh dengan kecenderungan Body Dysmorphic Disorder (BDD) pada remaja akhir laki-laki di Denpasar. Adapun derajat hubungan kedua variabel pada penelitian ini pada taraf sedang, dikarenakan ada faktor lain yang memengaruhi kecenderungan Body Dysmorphic Disorder (BDD) selain citra tubuh. Subjek pada penelitian ini memiliki citra tubuh dalam kategori sedang yang memiliki arti bahwa remaja akhir laki-laki di Denpasar merasa memiliki kekurangan pada tubuhnya namun masih merasa puas terhadap bentuk tubuhnya dengan melakukan berbagai cara untuk menutupi kekurangannya. Subjek pada penelitian ini memiliki kecenderungan Body Dysmorphic Disorder yang rendah, yang memiliki arti bahwa remaja akhir laki-laki yang memiliki kecenderungan Body Dysmorphic Disorder (BDD) yang rendah. 
Berdasarkan kesimpulan di atas, maka saran yang dapat diberikan kepada peneliti selanjutnya diharapkan dapat membuat aitem yang lebih bervariasi dan lebih mampu menggambarkan maksud dan tujuan dari penelitian, yaitu mengenai skala citra tubuh dan skala kecenderungan Body Dysmorphic Disorder (BDD). Bagi peneliti selanjutnya yang ingin melakukan penelitian mengenai hubungan antara citra tubuh dengan kecenderungan Body Dysmorphic Disorder (BDD) dapat memperbaharui skala kecenderungan Body Dysmorphic Disorder (BDD) yang digunakan pada penelitian ini. Kepada peneliti selanjutnya diharapkan dapat menyediakan waktu yang tepat pada dan menyesuaikan kondisi dan kesediaan subjek dalam melakukan penyebaran kuesioner dan dapat memeriksa ulang kuesioner yang telah diisi agar tidak terjadi kuesioner yang gugur. Diharapkan peneliti selanjutnya dapat mencari subjek remaja akhir lakilaki yang melakukan latihan otot untuk dapat lebih memperjelas kecenderungan Body Dysmorphic Disorder (BDD) pada laki-laki, ataupun dapat memperluas rentang usia remaja yang menjadi subjek penelitian yang juga mencakup remaja awal maupun remaja madya.

\section{DAFTAR PUSTAKA}

Ashari, J., A., \& Murti, H., A., S. (2017). Perbedaan body image remaja akhir laki-laki ditinjau dari keikutsertaan dalam gym. Skripsi. Fakultas Psikologi, Universitas Kristen Satya Wacana.

Azwar, S. (2015). Dasar-dasar psikometri. Yogyakarta: Pustaka Belajar.

Azwar, S. (2015). Penyusunan skala psikologi. Yogyakarta: Pustaka Belajar.

Azwar, S. (2015). Reliabilitas dan validitas. Yogyakarta: Pustaka Belajar.

Azwar, S. (2015). Tes prestasi. Yogyakarta: Pustaka Belajar.

Cash, T., F., \& Pruzinsky. (2002). Body image: A handbook of theory, research and clinical practice. London: Guilford Press

Cash, T. (2012). Encyclopedia of body image and human appearance. USA: Academic Press.

Ganeçwari, G. (2018). Studi Pendahuluan: Hubungan antara citra tubuh dengan kecenderungan body dysmorphic disorder pada remaja akhir laki-laki di Denpasar. Naskah tidak di publikasi. Program Studi Psikologi, Fakultas Kedokteran, Universitas Udayana.

Gracia, G. (2015). Hubungan antara body image terhadap kecenderungan body dysmorphic disorder pada mahasiswa PKK psikologi mercubuana jakarta yang melakukan selfie di media sosial (instagram atau facebook). Skripsi. Fakultas psikologi, Program Studi Psikologi, Universitas Mercu Buana.

Grogan, S. (1999). Body image: Understanding body dissatisfaction in men, women and children. USA: Routledge.

Grogan, S. (2008). Body image: Understanding body dissatisfaction in men, women and children (second edition). USA: Routledge.

Healey, J. (2014). Positive body image vol. 372. Australia: The Spinney Press.

Jones, D., C., \& Crawford, J., K. (2005). Adolescent boys and body image: Weight and uscularity concerns as dual pathways to body dissatisfaction. Journal of Youth and Adolescence, 35, 257-269.

Maharani, D. (2016). Tren bentuk tubuh ideal pria dari zaman dulu hingga kini. Diunduh dari https://lifestyle.kompas.com/read/2016/09/01/100300523/tr en.bentuk.tubuh.ideal.pria.dari.zaman.dulu.hingga.kini 28 Maret 2018.

McCabe, M., P. (2004). A longitudinal study of pubertal timing and extreme body change behaviors among adolescent boys and girls. 39 (153), 145-66.

Markey, C., N., \& Markey P., M. (2005). Relations between body image and dieting behaviors: An examination of gender differences. Sex Roles, Vol. 53, Nos. 7/8.

Odgen, J. (2010). The psychology of eating: From healthy to disordered behavior (second edition). USA: Blackwell Publishing.

Papalia, D. E., O., S., W., \& Feldman, R. D. (2008). Human Development (Psikologi Perkembangan Edisi Kesepuluh). Jakarta: Kencana.

Pramarta, L., \& Siswadi, A., G., P. (2015). Studi deskriptif mengenai citra tubuh remaja pria di SMA Negeri 11 kota bandung. Diunduh dari: http://repository.unpad.ac.id/20377/1/StudiDeskriptif-Mengenai-Citra-Tubuh-Pada-Remaja-Pria.pdf 15 November 2017.

Phillips, K. A. (2009). Understanding body dysmorphic disorder: An essential guide. New York: Oxford University Press.

Phillips K., A., Menard W., F., C (2006). Gender similarities and differences in 200 individuals with body dysmorphic disorder. Comprehensive Psychiatry, 47(2):77-87.

Rudd, N., A., \& Lennon, S., J. (2000). Body image and appearance management behaviors in college women. Clothing and Textiles Research Journal. 18 (3), 152-162.

Santrock, J., W. (2002). Life-span development, perkembangan masa hidup (edisi kelima). Jakarta: Erlangga.

Santrock, J., W. (2007). Adolescence: Perkembangan remaja. Jakarta: Erlangga.

Santrock, J., W. (2011). Remaja (edisi ke 11). Jakarta: Erlangga.

Sarwono. (2006). Psikologi remaja. Jakarta: Rajawali.

Sarwono. (2012). Psikologi remaja. Jakarta: PT. Raja Grafindo Persada.

Smolak, L., \& Thompson, K., J. (2009). Body image, eating disorders, and obesity in youth (second edition). Washington D.C: American Psychological Association.

Stuart, G., W., \& Laraia, M., T. (2005). Principle and practice of psychiatric nursing (Ed 8). St. Louis: The CV Mosby Year Book.

Sugiyono. (2016). Metode penelitian kombinasi (mixed methods). Bandung: Alfabeta.

Thompson, J., K., \& Altabe, M. (1990). Body image change during early adulthood. International Journal of Eating Disorder.

Waller, G., \& Barnes, J. (2002). Preconcious processing of body image cues: Impact on body perception and concept. Journal of Psychosomatic Research. 53, 1037-1041. 


\section{LAMPIRAN}

Tabel 1

Deskripsi Statistik Data Penelitian

\begin{tabular}{lcccccccc}
\hline Variabel & $\mathrm{N}$ & $\begin{array}{c}\text { Mean } \\
\text { Teoritis }\end{array}$ & $\begin{array}{c}\text { Mean } \\
\text { Empiris }\end{array}$ & $\begin{array}{c}\text { Std } \\
\text { Deviasi } \\
\text { Teoritis }\end{array}$ & $\begin{array}{c}\text { Std } \\
\text { Deviasi } \\
\text { Empiris }\end{array}$ & $\begin{array}{c}\text { Sebaran } \\
\text { Teoritis }\end{array}$ & $\begin{array}{c}\text { Sebaran } \\
\text { Empiris }\end{array}$ & $\mathrm{t}$ \\
\hline $\begin{array}{l}\text { Citra } \\
\text { tubuh }\end{array}$ & 208 & 62,5 & 63,51 & 12,5 & 6,791 & $25-100$ & $49-84$ & $\begin{array}{c}2,167 \mathrm{p} \\
= \\
(0,031)\end{array}$ \\
\hline $\begin{array}{c}\text { Kecender } \\
\text { ungan } \\
\text { BDD }\end{array}$ & 208 & 50 & 42,26 & 10 & 5,723 & $20-80$ & $26-57$ & $\begin{array}{c}-19,493 \\
\mathrm{p}= \\
(0,000)\end{array}$ \\
\hline
\end{tabular}

Tabel 2

Hasil Uji Normalitas Variabel Penelitian

Variabel

Kecenderungan BDD

Tabel 3

Hasil Uji Linearitas Variabel Penelitian

\begin{tabular}{cccccc}
\hline Model & Sum of Squares & Df & $\begin{array}{l}\text { Mean } \\
\text { Square }\end{array}$ & $\boldsymbol{F}$ & Sig. \\
\hline Linearity & 235.379 & 1 & 235.379 & 7.187 & 0,008 \\
\hline
\end{tabular}

Tabel 4

Hasil Uji Korelasi Pearson Product Moment

\begin{tabular}{rlrrr}
\hline & & CT & \multicolumn{1}{c}{ BDD } \\
\hline \multirow{2}{*}{ CT } & Pearson Correlation & 1 & $-0,186^{* *}$ \\
\cline { 2 - 5 } & Sig (2-tailed) & & 0,007 \\
\cline { 2 - 5 } & $\mathrm{N}$ & $-0,186$ & 208 \\
\hline \multirow{2}{*}{ BDD } & Pearson Correlation & 0,007 & 1 \\
\cline { 2 - 5 } & Sig (2-tailed) & 208 & 208 \\
\cline { 2 - 4 } & $\mathrm{N}$ & &
\end{tabular}

